\title{
介護老人保健施設における車椅子使用者の転倒リスク因子
}

\author{
今岡 真和 $* 1, * 2$ 樋口由 美*1 藤堂恵美子 $* 1$ \\ 北川智美*1 山口淳*3
}

\section{Risk Factors for Falls among Wheelchair Users in a Long-term Care Health Facility}

\author{
Masakazu Iмаока, ${ }^{* 1,} * 2$ Yumi Higuchi, ${ }^{* 1}$ Emiko Todo $* 1$ \\ Tomomi Kitagawa, ${ }^{* 1}$ Jun Yamaguchi ${ }^{* 3}$
}

\begin{abstract}
Purpose : The purpose of this study was to investigate the risk factors for falls among wheelchair users who were institutionalized in a long-term care health facility. Subjects : The participants were 62 new residents (mean age, 85.4 \pm 7.9 ) of a long-term care health facility. Methods : A longitudinal study of 6 months follow-up for falls was carried out. Baseline data were obtained regarding age, history of falls, functional status, psychological variables, physiological function, medical treatments and economic status. Risk factors for falls were analyzed by logistic regression. Results : During the follow-up, falls by 29 patients ( $46.8 \%$ of participants) were reported. Our analysis showed that four risk factors were significantly associated with falls : the patient had a bent back, a high FIM score, polypharmacy and benzodiazepine use. Logistic regression analysis revealed that a bent back was the best predictor of falls (OR 4.11 ; CI 95\% 1.25-13.5). (Jpn J Rehabil Med 2014; $51: 47-51$ )

要 旨 目的：本研究の目的は介護老人保健施設における車椅子使用者の転倒リスク因子を 明らかにすることである．対象：介護老人保健施設へ新規入所した者のうち，車椅子を日常生 活の移動手段とする 62 名（男性 14 名，女性 48 名，平均 $85.4 \pm 7.9$ 歳）であった. 方法：入所 時評価（ベースライン）は，年齢，過去 1 年間の転倒歴，身体機能，精神機能，生理機能，医 学的処置, 経済状況の 19 項目を評価した。転倒は入所から最長 6 力月間を前向きに追跡調査 した，統計解析は，単変量解析で転倒と有意に関連した項目を独立変数，転倒発生の有無を従 属変数としたロジスティック回帰分析を行った。結果：29名 $(46.8 \%)$ に転倒が発生した. 転倒に関連した項目は，「背中が丸くなってきた」「FIM 得点高値」「ベンゾジアゼピン系薬の 内服」「平均投薬数が多い」であった。ロジスティック回帰分析の結果, 入所期間中の転倒発 生に対して，「背中が丸くなってきた」が独立関連因子であった（オッズ比 4.11）.
\end{abstract}

Key words : 転倒（falls），車椅子（wheelchair）介護老人保健施設（long-term care health facility)

はじめに

高齢者全体の転倒率は年間 $28 ３ 5 \%$ であり，さら
に 70 歳以上の高齢者に限定すると転倒率は 30 $40 \%$ に上昇する ${ }^{1,2)}$ 。この転倒率は，年齢や虚弱の程 度と平行して増加する傾向があり, 施設に入所する要

2013 年 6 月 10 日受付, 2013 年 11 月 26 日受理

*1 大阪府立大学大学院総合リハビリテーション学研究科/ $=583-8555$ 大阪府羽曳野市はびきの 3-7-30

Graduate School of Comprehensive Rehabilitation, Osaka Prefecture University

*2 介護老人保健施設だいせんリハビリテーション科/～599-8234 大阪府堺市中区土塔町 155-1

Department of Rehabilitation Medicine, Long-term Care Health Facility Daisen

*3 大阪市立総合医療センターリハビリテーション科/テ 534-0021 大阪府大阪市都島区都島本通 2-13-22

Department of Rehabilitation Medicine, Osaka City General Hospital

E-mail : imaokamasakazu@hotmail.co.jp 
介護高齢者では，地域に暮らす高齢者よりも転倒率は $2 \sim 3$ 倍高いとされる ${ }^{3)}$. 転倒発生のリスク因子につ いては数多くの探索的研究から, 特に, 過去 1 年間の 転倒歴, 歩行能力やバランス能力の低下が上位に挙げ られる ${ }^{4)}$. 介護老人保健施設（以下，老健施設）入所 者のほとんどは, 先述の転倒リスク因子を全て有して 抢り，その約 $70 \%$ が日常生活の移動手段として車椅 子を使用している5 。車椅子を移動手段とする高齢者 は，歩行可能な者に比べて転倒リスクは高いことが知 られている ${ }^{6}$. そのため，転倒ハイリスクで車椅子生 活を行う者が多い老健施設では，より転倒しやすい要 因を分析し，転倒予防対策を講じる必要がある。そこ で本研究では，老健施設に入所する車椅子使用者の転 倒リスク因子を明らかにすることを目的とした。

\section{対象と方法}

\section{1. 対象}

対象は 2011 年 7 月から 2013 年 1 月までの 19 カ月 間に，大都市近郊 $\mathrm{A}$ 介護老人保健施設一新規入所し た 75 名のうち，車椅子を日常生活の移動手段とする 者 62 名を取り込み対象とした。車椅子使用者であっ ても，障害老人の日常生活自立度判断基準で $\mathrm{C} 2$ レ心 ルの者は対象から除外した。性別の内訳は男性 14 名, 女性 48 名, 平均年齢 $85.4 \pm 7.9$ 歳（62〜101歳）で あった。観察はそれぞれの入所時から最長 6 力月間を 追跡した。

対象者と家族に対して本研究の趣旨を十分に説明 し，書面および口頭にて同意を得た。また，認知症に より研究対象者の同意確認が困難な場合には, 代諾者 の同意をもって対象者の同意とみなした。本研究は当 大学総合リハビリテーション学研究科倫理委員会の承 認（承認番号 2011 P 03）を得て実施した。

\section{2. 評価方法}

入所日にベースライン評価を実施した。評価項目 は, 先行研究 ${ }^{7 ~ 16)} に$ に虚弱高齢者の転倒と関連が報 告される 19 項目とした。各評価項目は，以下のよう にカテゴリー化した：転倒歴 ${ }^{7)}$, 身体機能, 精神機能, 生理機能，医学的処置，経済状況とした。それぞれの 回答は有無を問う 2 択式で構成し, 連続変数のデー夕 は，身体機能に含む Functional Independence Measure（以下 FIM），精神機能に含む長谷川式簡易知能 評価スケール (以下 HDS-R)，医学的処置に含む薬剂 投与数の 3 項目であった.
身体機能に含む項目のうち実際に機能評価を実施し た項目は，下肢筋力低下 (Manual Muscle Testing に よる膝関節伸展 4 以下 $)^{4)}$, 方向転換能力低下（立位 で $360^{\circ}$ 回転する所要時間が 4 秒以上 $)^{4)}$ 抢よび，FIM であった，対象者もしくは家族へ質問調查した項目 は，背中が丸くなってきたか ${ }^{8)}$, 慢性的な疼痛がある が)，であった。

精神機能に含む暴言・暴力の有無 ${ }^{9)}$ は，看護要約 から収集した. HDS-Rの評価は理学療法士が実施し た。

生理機能に含む頻回な排泄（日中 8 回以上，もしく は夜間 2 回以上) ${ }^{10)}$ の有無抒よび，昼夜の排泄場所が 異なるか（例：日中はフロアトイレ，夜間はポータブ ルトイレ使用 $)^{11}$ については，看護・介護記録から確 認した。足底感覚障害の有無は, 理学療法士が足底の 触覚検查 ${ }^{12)}$ を行い評価した。測定方法は綿棒で検査 部位を触れ，刺激が分かった段階で触れた部位を被験 者に答えさせた。

医学的処置には一日の薬剤投与数，転倒を誘因する と報告される向精神薬内服 ${ }^{14}$, 睡眠導入剂内服 ${ }^{14)}$, 抗 不安薬内服 ${ }^{13)}$, ベンゾジアゼピン系薬内服 ${ }^{14)}$ の投薬 状況を調查した. 加えて, 認知機能の低下 ${ }^{4)}$ や円背 ${ }^{8)}$ が転倒リスクを上昇させることから，アルッハイマー 型認知症治療薬，骨粗鬆症薬の内服状況についても調 査した。これらは診療情報提供書揖よび看護要約から 確認した.

経済状況 ${ }^{15)}$ は, 介護保険の利用者負担段階で第 2 および第 1 段階を低所得と分類した。

\section{3. 転倒の追跡調査}

入所から最長 6 カ月間の転倒を前向きに調査した. 転倒の定義は，Gibson の定義 ${ }^{16)}$ および世界保健機関 （WHO）による国際疾病分類の転倒・転落に基づい た。そのため, 本研究では車椅子からのずり落ちも転 倒として取り扱った。転倒状況は，施設で使用するイ ンシデント・アクシデント報告書から確認した.

\section{4. 統計解析}

ベースラインの評価項目に対する転倒・非転倒の 2 群比較には，対応のない $\mathrm{t}$-検定および $\chi^{2}$ 検定を用い た。次に，転倒と有意な関連を認めた項目を独立変数 とし，転倒の有無を従属変数としたロジスティック回 帰分析を行った。統計ソフトはSPSS ver.20を使用し， 有意水準は $5 \%$ 未満とした. 
表 1 対象者の基本属性

\begin{tabular}{lcccc}
\hline & & \multicolumn{2}{c}{ 車椅子 } & \\
\cline { 3 - 4 } & 全体 & 非転倒 & 転倒 & \multirow{2}{*}{ 值 } \\
& $N=62$ & $n=33$ & $n=29$ & \\
\hline 性別 (男性/女性) & $14 / 48$ & $7 / 26$ & $7 / 22$ & 0.783 \\
年齢 (歳) & $85.4 \pm 7.9$ & $86.4 \pm 7.5$ & $84.2 \pm 8.4$ & 0.275 \\
身長 $(\mathrm{cm})$ & $147.8 \pm 8.9$ & $146.8 \pm 9.5$ & $149.0 \pm 8.3$ & 0.349 \\
体重 $(\mathrm{kg})$ & $44.4 \pm 9.4$ & $43.7 \pm 10.7$ & $45.2 \pm 7.8$ & 0.535 \\
BMI & $20.1 \pm 3.1$ & $19.8 \pm 3.4$ & $20.4 \pm 2.8$ & 0.499 \\
入所期間 (日) & $174.6 \pm 25.1$ & $178.3 \pm 13.8$ & $170.5 \pm 33.5$ & 0.253 \\
\hline
\end{tabular}

数值は, $n \pm(\mathrm{SD})$. BMI : Body Mass Index

\section{結果}

\section{1. 転倒の発生について}

対象者の転倒観察期間は $174.6 \pm 25.1$ 日（49〜 184 日）であり，53 名 $(84.2 \%)$ は最長観察期間の 6 力 月を調查した。対象者 62 名のうち観察期間に転倒し た者は 29 名 $(46.8 \%)$ ，複数回以上転倒した者は 29 名中 16 名であった．転倒者のうち 1 名は骨折（肋骨 骨折)，2名が打撲に至った。残りの 26 名に目立った 外傷は認めなかった。

転倒者 29 名のうち, 入所から 2 力月以内に 23 名 (79.3\%) は転倒した。また，非転倒群と転倒群の基 本属性に有意な差は見られなかった（表 1)，初回転 倒 29 件の発生場所は居室が最も多く，車椅子使用者 は居室つまりベッドサイド周辺の転倒事象が 20 件 （69\%）であった（表 2)。

\section{2. 車椅子使用者の転倒リスク因子}

ベースライン評価項目について，入所期間中の転倒 有無で比較した結果を表 3 に示す。身体機能のうち, 「背中が丸くなってきた」の回答は転倒群が有意に多 かった。FIM 得点は, 転倒群で有意に得点が高い結 果となった。医学的処置では, ベンゾジアゼピン系薬 の使用は転倒群で有意に多かった。薬郕投与数は転倒 群が有意に多かった。

単変量解析にて車椅子使用者の転倒と非転倒に有意 差を認めた「背中が丸くなってきた」「FIM 得点」「べ ンゾジアゼピン系薬内服」「薬剤投与数」の 4 要因を 独立変数に，入所期間中の転倒有無を従属変数として ロジスティック回帰分析を実施した（表 4)。その結 果，「背中が丸くなってきた」のみが車椅子使用者の 転倒発生に対する独立関連因子（オッズ比 4.11）で あった。
表 2 転倒発生状況の内訳

\begin{tabular}{|c|c|c|c|}
\hline $\begin{array}{c}\text { 対象者 } \\
\text { ID } \\
\end{array}$ & $\begin{array}{l}\text { 転倒 } \\
\text { 場所 }\end{array}$ & 転倒に至った行動 & $\begin{array}{c}\text { 転倒 } \\
\text { 時間帯 }\end{array}$ \\
\hline 1 & 居室 & トイレへ行くため車椅子に移乗 & $4: 40$ \\
\hline 2 & 居室 & 車椅子からベッドへ移乗 & $13: 15$ \\
\hline 3 & 居室 & タンス整理のため立ち上がり & $10: 00$ \\
\hline 4 & 居室 & トイレへ行くため車椅子に移乗 & $5: 45$ \\
\hline 5 & 居室 & ポータブルトイレへ移乗 & $5: 15$ \\
\hline 6 & 居室 & トイレへ行くため車椅子に移乗 & $10: 30$ \\
\hline 7 & 居室 & ベッド端から立ち上がり & $2: 00$ \\
\hline 8 & 居室 & トイレへ行くため車椅子に移乗 & $4: 00$ \\
\hline 9 & 居室 & ポータブルトイレへ移乗 & $2: 25$ \\
\hline 10 & 居室 & トイレへ行くため車椅子に移乗 & $2: 55$ \\
\hline 11 & 居室 & カーテンを閉めるため立ち上がり & $16: 40$ \\
\hline 12 & 居室 & 車椅子からベッドへ移乗 & $14: 20$ \\
\hline 13 & 居室 & 車椅子からベッドへ移乗 & $6: 50$ \\
\hline 14 & 居室 & トイレへ行くため車椅子に移乗 & $21: 05$ \\
\hline 15 & 居室 & ポータブルトイレへ移乗 & $21: 20$ \\
\hline 16 & 居室 & ベッドから車椅子へ移乗 & $6: 45$ \\
\hline 17 & 居室 & トイレへ行くため車椅子に移乗 & $8: 20$ \\
\hline 18 & 居室 & 車椅子からベッドへ移乗 & $19: 00$ \\
\hline 19 & 居室 & 車椅子からベッドへ移乗 & $18: 20$ \\
\hline 20 & 居室 & 車椅子からベッドへ移乗 & $16: 10$ \\
\hline 21 & トイレ & 便座から車椅子へ移乗 & $7: 00$ \\
\hline 22 & トイレ & 車椅子から便座へ移乗 & $9: 30$ \\
\hline 23 & トイレ & 便座から車椅子へ移乗 & $13: 00$ \\
\hline 24 & トイレ & 便座から車椅子へ移乗 & $15: 50$ \\
\hline 25 & トイレ & 便座から車椅子へ移乗 & $5: 05$ \\
\hline 26 & 食堂 & 車椅子上からずり落ち & $21: 15$ \\
\hline 27 & 食堂 & 立ち上がり後バランスを崩す & $5: 40$ \\
\hline 28 & 廊下 & 車椅子上で本を拾うため前傾 & $13: 30$ \\
\hline 29 & 廊下 & 車椅子上からずり落ち & $6: 30$ \\
\hline
\end{tabular}

\section{考察}

老健施設に入所する車椅子使用者の転倒リスク因子 を明らかにすることを目的に前向き調查を行った結 果，「背中が丸くなってきた」「FIM 得点」「ベンゾジ アゼピン系薬内服」「薬郕投与数」が転倒と有意に関 
表 3 ベースライン評価の転倒リスク因子単変量解析結果

\begin{tabular}{|c|c|c|c|c|c|}
\hline & & \multicolumn{3}{|c|}{ 車椅子 } & \multirow[b]{2}{*}{$p$ 值 } \\
\hline & & $\begin{array}{c}\text { 全体 } \\
N=62\end{array}$ & $\begin{array}{c}\text { 非転倒 } \\
n=33\end{array}$ & $\begin{array}{c}\text { 転倒 } \\
n=29\end{array}$ & \\
\hline 転倒歴 & 過去 1 年間の転倒 & $36(58.1)$ & $18(54.5)$ & $18(62.1)$ & 0.549 \\
\hline \multirow[t]{5}{*}{ 身体機能 } & 背中が丸くなってきた & $25(46.3)$ & $8(24.2)$ & $17(58.6)$ & 0.006 \\
\hline & 慢性疼痛がある & $27(43.5)$ & $11(33.3)$ & $16(55.2)$ & 0.084 \\
\hline & 下肢筋力低下 & $59(95.2)$ & $31 \quad(93.9)$ & $28(96.6)$ & 0.632 \\
\hline & 方向転換能力低下 & $59(95.2)$ & $31(93.9)$ & $28(96.6)$ & 0.632 \\
\hline & FIM 得点 & $73.0 \pm 22.9$ & $70.0 \pm 23.4$ & $79.9 \pm 21.0$ & 0.024 \\
\hline \multirow[t]{2}{*}{ 精神機能 } & 暴言・暴力がある & $4(6.5)$ & $2(6.1)$ & $2(6.1)$ & 0.894 \\
\hline & HDS-R 20 点以下 & $47(75.8)$ & $27(81.8)$ & $20(69.0)$ & 0.238 \\
\hline \multirow[t]{3}{*}{ 生理機能 } & 頻回な排泄がある & $13(21.0)$ & $8(24.2)$ & $5(17.2)$ & 0.499 \\
\hline & 昼夜の排泄場所が異なる & $42(74.2)$ & $21(63.6)$ & $21(72.4)$ & 0.461 \\
\hline & 足底感覚障害 & $16(25.8)$ & $6(18.2)$ & $10(34.5)$ & 0.143 \\
\hline \multirow[t]{7}{*}{ 医学的処置 } & 向精神薬 & $4(6.5)$ & $1(3.0)$ & $3(10.3)$ & 0.242 \\
\hline & 抗不安薬 & $9(14.5)$ & $3(9.1)$ & $6(20.7)$ & 0.196 \\
\hline & ベンゾジアゼピン系薬 & $10(16.1)$ & $2(6.1)$ & $8(27.6)$ & 0.021 \\
\hline & 認知症治療薬 & $3(4.8)$ & $1(3.0)$ & $2(6.9)$ & 0.479 \\
\hline & 骨粗鬆症薬 & $3(4.8)$ & $2(6.1)$ & $1(3.0)$ & 0.632 \\
\hline & 睡眠導入剂 & $4(6.5)$ & $2(6.1)$ & $2(6.9)$ & 0.894 \\
\hline & 薬剂投与数 & $4.3 \pm 2.7$ & $3.6 \pm 2.6$ & $5.0 \pm 2.6$ & 0.046 \\
\hline 経済状況 & 低所得区分 & $36(51.8)$ & $19(57.6)$ & $17(58.6)$ & 0.934 \\
\hline
\end{tabular}

数值は, $n \pm(\mathrm{SD})$ または $n(\%)$

表 4 車椅子使用者の転倒リスク因子

\begin{tabular}{lcll}
\hline \multicolumn{1}{c}{ リスク因子 } & オッズ比 & $95 \%$ 信頼区間 & $p$ 值 \\
\hline ベンゾジアゼピン系薬内服 & 4.16 & $0.596-28.997$ & 0.150 \\
背中が丸くなってきた & 4.11 & $1.255-13.503$ & 0.020 \\
薬剤投与数 & 1.10 & $0.851-1.419$ & 0.470 \\
FIM 得点 & 1.03 & $0.999-1.053$ & 0.063 \\
\hline
\end{tabular}

連した。これら 4 要因を独立変数としたロジスティッ ク回帰分析では,「背中が丸くなってきた」のみが車 椅子使用者の転倒に対するリスク因子であった。

「背中が丸くなってきたか」という質問項目は，ア ライメント変化を問うことでマルアライメントを間接 的に聴取している. 先行研究 ${ }^{17)} に て$ 転倒しやすい者 は，そうでない者に比べて脊柱の後弯が強く, 腰椎の 可動性低下および金柱起立筋の筋力低下が有意にある とされており，また別の報告では背中が丸くなり壁立 ち立位にて後頭部が離れる者は，そうでない者と比べ てバランス能力が低下していることが報告されてい る ${ }^{18)}$. つまり, 車椅子使用者の中でも体幹の筋力が低 下している者や，体幹の分節的な可動性が低下してい る者は転倒リスクが上昇することを示唆している．そ
のため，立位バランステストを行えない車椅子使用者 では，静的アライメントの評価を行うことで転倒リス クを客観的に把握できる可能性がある。この「背中が 丸くなってきたか」は，利用者自身もしくは家族が主 観的にアライメント変化を感じているかを問う質問項 目であり，いつから背中が丸くなってきたかという時 間の定義は先行研究 ${ }^{8)}$ 同様に行わなかった.

背中が丸くなることは骨粗鬆症との関連も指摘され ており，身長が 25 歳の時から $4 \mathrm{~cm}$ 以上短縮した者 は椎体骨折の相対危険率は 2.8 倍とされ ${ }^{19)}$, 転倒後の 重篤な骨折へのリスクが高い。近年, 骨粗鬆症研究の 中で $3 \sim 6$ 力月間のビタミン $\mathrm{D}$ 製剂投与による転倒 率の低下が報告 ${ }^{20)}$ されている点から, 積極的な骨粗 磼症薬物療法は，比較的入所期間が短い老健施設にお いて，転倒予防の有効な一手段となる可能性がある. 本研究では骨粗鬆症治療を行っていた者は全体で 3 名 と少なく転倒との関連性は明らかにならなかった。老 健施設では，比較的薬価の高い骨粗鬆症治療薬を積極 的に導入できない経済的側面もあり，介護保険領域の 施設入所者に対する骨粗鬆症治療および転倒予防対策 にとって大きな課題である. 
研究対象施設では，転倒が発生した場合に医師・看 護師・介護福祉士 ・理学療法士による転倒対策カン ファレンスを行い, 居室環境の変更や調整により再転 倒予防を図っていたが，2回目以降の転倒を十分に防 ぐことができなかった．従来実施してきた居室環境の 整備に加え，今後は投薬の見直し等を実施し，車椅子 使用者の転倒予防に有効な介入方法を検討する必要性 がある。

本研究の限界は, 単一施設のみが調査対象でありサ ンプルサイズが小さい点である．また，施設入所の対 象者は入所判定会議で入所可能か判断されているた め，選択バイアスをコントロールできていない。 これ らの課題を解決するために多施設間研究が必要であ る.

\section{文献}

1) Prudham D, Evans JG : Factors associated with falls in the elderly : a community study. Age Aging $1981 ; 10$ : 141-146

2) Campbell AJ, Reinken J, Allan BC, Martinez GS : Falls in old age : a study of frequency and related clinical factors. Age Aging $1981 ; 10: 264-270$

3) Rubenstein LZ, Josephson KR, Robbins AS : Fall in the nursing home. Ann Intern Med $1994 ; 121$ : 23-29

4) Panel on Prevention of Falls in Older Persons, American Geriatrics Society and British Geriatrics Society. Summary of the updated American Geriatrics Society/British Geriatrics Society clinical practice guideline for prevention of falls in olderpersons. J Am Geriatr Soc 2011 ; 59 : 148-157

5）今岡真和, 樋口由美, 吳本冬馬, 藤堂恵美子 : 介護老人保 健施設における車椅子使用者の転倒の特徵. 理学療法 科学 $2012 ; 27: 257-261$

6) Brians LK, Alexander K, Grota P, Chen RW, Dumas V : The development of the RISK tool for fall prevention. Rehabil Nurs $1991 ; 16: 67-69$

7) Morse JM, Black C, Oberle K, Donahue P : A prospective study to identify the Fall-Prone patient. Soc Sci Med $1989 ; 28: 81-86$

8) Okochi J, Toba K, Takahashi T, Matsubayashi K, Nishinaga M, Takahashi R, Ohrui T : Simple Screening test for risk of fall in the elderly. Geriatric Gerontol Int 2006 ; $6: 223-227$
9) Wang J, Chang LH, Eberly LE, Virnig BA, Kane RL : Cognition moderates the relationship between facility characteristics, personal impairments, and nursing home residents actives of daily living. J Am Geriatr Soc 2010 ; 58 : 2275-2283

10) Oliver D, Britton M, Seed P, Martin FC, Hopper AH : Development and evaluation of evidence based risk assessment tool (STR-ATIFY) to predict which elderly inpatients will fall : case-control and cohort studies. BMJ 1997 ; $315: 1049-1053$

11）平松知子, 泉キヨ子, 正源寺美穂 : 施設高齢者の転倒予 防一排泄に関連した転倒者の排泄状況及び転倒の実 態一. 老年看護学 $2006 ; 11: 47-52$

12）鈴木敏明 編 : 臨床理学療法評価法. エンタプライズ株 式会社, 東京, 2003; pp 215-216

13）秋下雅弘：高齢者の安全な薬物療法ガイドライン. 日本 老年医学会雑誌 $2007 ; 44(31): 31-34$

14）高橋佳苗, 長尾能雅, 足立由起, 森本 剛, 市橋則明, 坪 山直生, 大森 崇, 佐藤俊哉: 高齢者におけるベンゾジ アゼピン系薬の服薬量変更と転倒との関連 : 急性期病 院入院患者を対象にした解析. 薬剤疫学 $2011 ; 16: 11-$ 20

15）松田亮三, 平井 寛, 近藤克則 : 高齢者の保健行動と転 倒歴: 社会経済的地位との相関. 公衆衛生 $2005 ; 69$ : 231-235

16) Gibson MJ : Falls in later life. in Improving the Health of Older People : A World View. Oxford University Press, New York, 1990 ; pp 296-315

17) Kasukawa K, Miyakoshi N, Hongo M, Ishikawa Y, Noguchi H, Kamo K, Sasaki H, Katsuyuki M, Shimada Y : Relationships between falls, spinal curvature, spinal mobility and back extensor strength in elderly people. J Bone Miner Metab $2010 ; 28: 82-87$

18) Balizini L, Vannucchi L, Benvenuti F, Benucci M, Monni M, Cappozo A, Stanhope S : Clinical Characteristics of Flexed Posture in Elderly Woman. J Am Geriatr Soc 2003 ; 51 : 1419-1426

19) Vogt TM, Ross PD, Palermo L, Musliner T, Genant HK, Black D, Thompson DE : Vertebral fracture prevalence among women screened for the Fracture intervention trial and a simple clinical tool to screen for undiagnosed vertebral fracture. Fracture Intervention Trial Research Group. Mayo Clin Proc 2000 ; 75 : 888-896

20) Bischoff HA, Dawson B, Staehelin HB, Orav JE, Stuck AE, Theiler R, Wong JB, Egli A, Kiel DP, Henschkowski $\mathrm{J}$ : Fall prevention with supplemental and active forms of vitamin $\mathrm{D}$ : a meta-analysis of randomised controlled trials. BMJ 2009 ; 399 : 1-11 